\title{
Diet quality index for healthy food choices
}

\author{
Índice de qualidade da dieta para \\ escolhas alimentares saudáveis
}

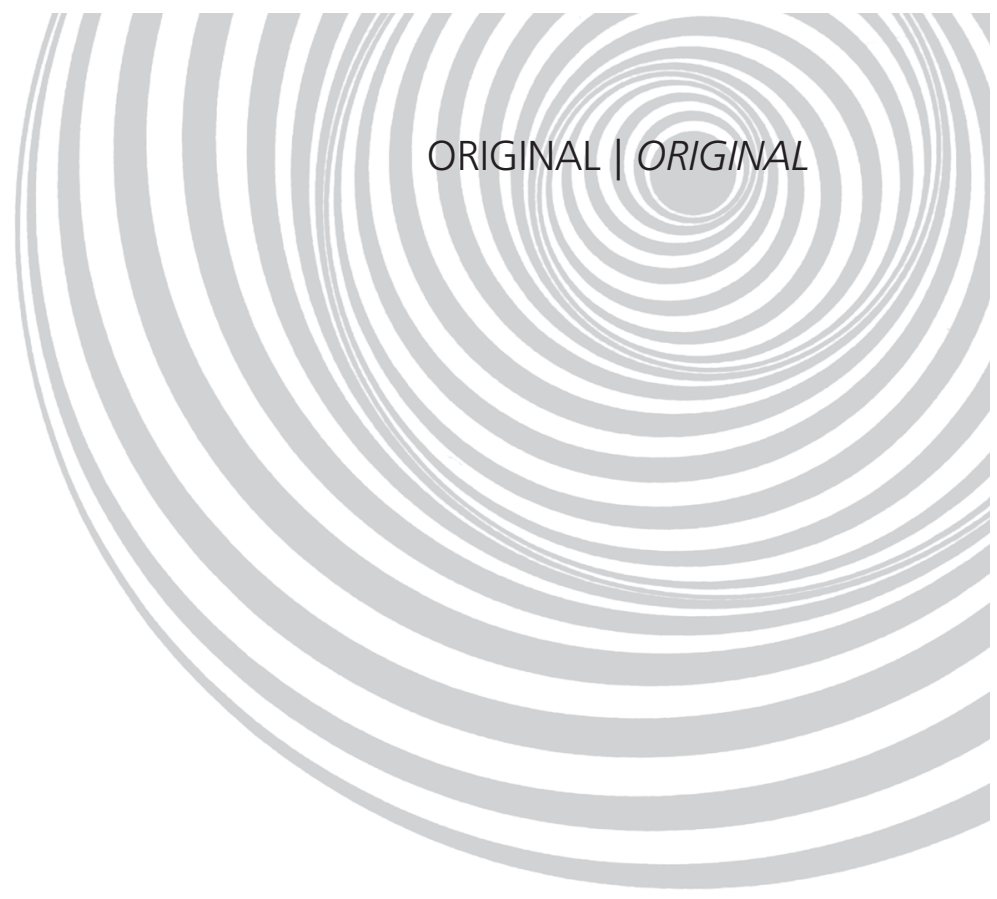

Simone CAIVANO ${ }^{1}$

Semíramis Martins Álvares DOMENE²

A B S T R A C T

\section{Objective}

To present a Diet Quality Index proper for dietary intake studies of Brazilian adults.

\section{Methods}

A diet quality index to analyze the incorporation of healthy food choices was associated with a digital food guide. This index includes moderation components, destined to indicate foods that may represent a risk when in excess, and adequacy components that include sources of nutrients and bioactive compounds in order to help individuals meet their nutritional requirements. The diet quality index-digital food guide performance was measured by determining its psychometric properties, namely content and construct validity, as well as internal consistency.

\section{Results}

The moderation and adequacy components correlated weakly with dietary energy (-0.16 to 0.09). The strongest correlation (0.52) occurred between the component 'sugars and sweets' and the total score. The Cronbach's coefficient alpha for reliability was 0.36 .

\section{Conclusion}

Given that diet quality is a complex and multidimensional construct, the Diet Quality Index-Digital Food Guide, whose validity is comparable to those of other indices, is a useful resource for Brazilian dietary studies. However, new studies can provide additional information to improve its reliability.

Indexing terms: Eating. Food guide. Food quality. Health food.

\footnotetext{
${ }^{1}$ Universidade Federal de São Paulo, Instituto Saúde e Sociedade, Programa de Pós-Graduação Interdisciplinar em Ciências da Saúde. Av. Ana Costa, 95, Campus Baixada Santista, Vila Mathias, 11060-001, Santos, SP, Brasil. Correspondência para/Correspondence to: S CAIVANO.E-mail: <simone.caivano@hotmail.com>.

2 Universidade Federal de São Paulo, Instituto Saúde e Sociedade, Departamento de Políticas Públicas e Saúde Coletiva. Santos, SP, Brasil.
} 
694 | S CAIVANO \& SMA DOMENE

\section{RE S U M O}

\section{Objetivo}

Apresentar um Índice de Qualidade da Dieta com aplicação para estudos de ingestão alimentar de brasileiros adultos.

\section{Métodos}

Para analisar a incorporação de escolhas alimentares saudáveis desenvolveu-se o Índice de Qualidade da Dieta associado a um Guia Alimentar Digital. Este Índice é constituído por componentes de moderação, destinados a indicar alimentos fonte de compostos associados a risco quando em excesso, e componentes de adequação, que incluem alimentos fonte de nutrientes e compostos bioativos de forma a atender às recomendações nutricionais. A avaliação de desempenho do Índice de Qualidade da Dieta associado a um Guia Alimentar Digital foi medida a partir de suas propriedades psicométricas para validação de conteúdo, construto e consistência interna.

\section{Resultados}

Os valores de correlação entre os componentes de moderação e de adequação em relação à energia da dieta foram fracos $(-0,16$ a 0,09); a mais alta correlação $(0,52)$ ocorreu entre o componente açúcares e doces e a pontuação total; a confiabilidade apresentou $\alpha=0,36$.

\section{Conclusão}

Sabendo-se que a qualidade da dieta é uma construção complexa e multidimensional, o Índice de Qualidade da Dieta associado a um Guia Alimentar Digital é um recurso com validade compatível à observada para outros Índices e que pode contribuir para estudos de ingestão alimentar na população brasileira. Contudo, novos estudos devem promover ajustes para aprimorar a confiabilidade do instrumento.

Termos de indexação: Ingestão de alimentos. Guias alimentares. Qualidade dos alimentos. Alimentos naturais.

\section{INTRODUCTION}

The Brazilian Household Budget Survey of 2008-2009 reported that more than half of the adult Brazilian population was overweight, and $12.4 \%$ of the individuals were obese ${ }^{1}$. Steemburgo et al. ${ }^{2}$ found that $25.4 \%$ of the population have chronic diseases and the Metabolic Syndrome (MS). Healthy diets play an important role in the prevention of chronic diseases, and food guides can be a strategy for promoting them ${ }^{3}$.

Food guides aim to convert the scientific knowledge on nutrition into concepts that are easy to understand, enabling most people to make healthy food choices ${ }^{4}$. New findings about the relationship between diet and health were incorporated into guidelines to prevent nutritional deficiencies and chronic diseases ${ }^{3}$.

Diet quality indices based on what is known about healthy diets have been proposed to assess individuals' diets in population studies and to facilitate diet monitoring in order to prevent Non-communicable Chronic Diseases (NCD) and nutritional deficiencies ${ }^{5}$. The development of indices and other tools for diet quality assessment began in $1980^{6}$. In 2007, twenty different diet quality indices were available, and in 2009, this number had jumped to $25^{7}$. Among those indices, the Healthy Eating Index (HEl-05) ${ }^{8}$, developed for the North American population, stands out. In 2011, the HEl was updated $^{9}$ to incorporate the new Dietary Guidelines for Americans ${ }^{10}$. In Brazil, Fisberg et al. ${ }^{11}$ published an adaptation of the $\mathrm{HEI}$, resulting in the Brazilian Diet Quality Index (DQI). Previdelli et al. ${ }^{12}$ reviewed this index (DQI-R) after the Brazilian Food Guide was published ${ }^{13}$.

The objective of the present study is to propose a diet quality index adjusted to energy content, enabling studies to measure the incorporation of healthy food choices by Brazilian adults. 


\section{METHODS}

\section{Data collection and study participants' characteristics}

Data collection. A retrospective cohort study collected the food intake data recorded by users of the application software NutraBem ${ }^{(3)}$ for the operating system iOS for smartphones ${ }^{14}$. The study was approved by the Research Ethics Committee of the Universidade Federal de São Paulo under protocol number $n^{\circ} 1823 / 11$, on November 18, 2011. A total of 662 respondents signed the Free and Informed Consent Form sent to the 23,137 individuals who purchased the application between 2009, when it was launched, and May 2011, when the study ended. Of the signees, 476 met the inclusion criteria, which were having recorded at least three meals, being adults and have no food restrictions. Thirty-four records were discarded because of data inconsistency, so the final sample consisted of 442 subjects.

The study collected one 24-hour dietary data of each participant. The data were converted into food groups and the corresponding number of servings as recommended by the proposed Diet Quality Index - Digital Food Guide (DQI-DFG).

The use of digital technology for recording dietary data is an innovation that has been experimented successfully in other countries ${ }^{7}$, and its usability in Brazil has proven to be promissing ${ }^{14}$. The software was developed to promote national foods organized according to the adapted Harvard School of Public Health's proposal15-17.

Study participants' characteristics. The sample consisted of adult males and females (59\%) aged 19 to 50 years (64\% aged more than 31 years) with sedentary jobs, not pregnant or breastfeeding, and not undergoing diseaserelated dietary interventions. All users of the NutraBem application must meet these conditions. Although the socioeconomic data of the users are unknown, NutraBem requires an operating system that was only available to the more expensive smartphones in Brazil at the time of data collection. Therefore, the socioeconomic profile of the respondents should not bias data interpretation.

\section{Diet Quality Index - DQI-DFG}

The Diet Quality Index - Digital Food Guide consists of twelve components grouping common foods in Brazil ${ }^{1}$ according to international consensus on diet and health (Table 1). The index has a maximum score of 100 points subdivided as follows: 0 to 49 points: low-quality diet; 50 to 79 points: intermediate-quality diet; 80 or more points: good-quality diet. The twelve components are distributed between moderation and adequacy components as follows:

Components 1 to 4: Moderation components. The reference number of servings for these components are based on the risk they pose when abused: sugars and sweets, beef and pork, refined grains and breads, and animal fat ${ }^{15-17}$. Reference numbers of servings with a maximum score of 5 or 10 points were established for these components to prevent the inclusion of excess refined carbohydrates, foods with high glycemic index, and foods high in saturated fats in the diet. Thus, when individuals consume more than the reference values, these components receive a score of zero. These components have a dichotomous score of either 5 or 10 points when their consumption is within the reference values, and zero when above the reference values.

Components 5 to 12: Adequacy components. These components include the food groups that supply the nutrients and bioactive compounds that individuals need to meet their nutritional requirements. The reference number of servings established for poultry, seafood, and eggs; whole grains and breads; tubers and roots; fruits; non-starchy vegetables; legumes; milk and dairy products; and nuts and vegetable oils help

(3) This app is a product of technological innovation, developed through a partnership between the University and Instituto Nutra e Viva, an organization that works with projects in nutrition and food education. 
696 | S CAIVANO \& SMA DOMENE

Table 1. Components and score of the Diet Quality Index - Digital Food Guide (DQI-DFG). Brazil, 2013.

\begin{tabular}{|c|c|c|c|}
\hline \multirow[t]{2}{*}{ Component (kcal/serving) } & \multirow[t]{2}{*}{ Maximum score } & \multicolumn{2}{|c|}{$\begin{array}{cc}\text { Reference value } & \text { Reference value } \\
\text { for a score of zero }\end{array}$} \\
\hline & & \multicolumn{2}{|c|}{ (n servings/1000kcal) } \\
\hline \multicolumn{4}{|l|}{ Moderation components ${ }^{1}$} \\
\hline 1. Sugars and sweets (72) & 10 & $\leq 0.5$ & $>0.5$ \\
\hline 2. Beef or pork (105) & 5 & $\leq 0.5$ & $>0.5$ \\
\hline 3. Refined grains and breads (140) & 5 & $\leq 0.5$ & $>0.5$ \\
\hline 4. Animal fat (60) & 10 & $\leq 0.5$ & $>0.5$ \\
\hline \multicolumn{4}{|l|}{ Adequacy components ${ }^{2}$} \\
\hline 5. Poultry, seafood, and eggs (140) & 10 & $\geq 1$ & Not consumed \\
\hline 6. Whole grains and breads, tubers and roots (whole grains: 140/tubers: 75) & 10 & $\geq 2$ & Not consumed \\
\hline 7. Fruits (100) & 10 & $\geq 1.5$ & Not consumed \\
\hline 8. Non-starchy vegetables (vegetables: 40/leaf vegetables: 10) & 10 & $\geq 2$ & Not consumed \\
\hline 9. Legumes (150) & 5 & $\geq 1$ & Not consumed \\
\hline 10. Milk and dairy products (milk and yogurt: 120/cheese: 80 ) & 10 & $\geq 0.75$ & Not consumed \\
\hline 11. Nuts (50) & 5 & $\geq 0.25$ & Not consumed \\
\hline 12. Vegetable oils (72) & 10 & $\geq 1$ & Not consumed \\
\hline
\end{tabular}

Note: ${ }^{1}$ Dichotomous score; ${ }^{2}$ Score increases with intake up to the reference standard.

adults to meet their nutritional requirements when combined. The maximum score of 5 or 10 points for these components is reached when individuals consume at least the reference number of servings. If no food of a group is consumed, the group receives a score of zero. Inadequate intake of a food group is scored accordingly.

Food servings were adjusted to an intake of $1000 \mathrm{kcal}$. This practice enables analysis of diet quality regardless of the absolute amounts consumed of food groups that promote an overestimation of high-energy diet scores. Energy adequacy, indicated by a stable and healthy body weight, is also an important attribute of diet quality.

\section{DQI-DFG construct validity and reliability analysis}

Validation protocol. The DQI-DFG performance was investigated by its psychometric properties. The study used the HEI-05 to model the organization of food groups into moderation and adequacy components ${ }^{8}$. Given that food intake is positively correlated with energy intake, the DQI-DFG score of high-energy diets could have been overestimated. The correlation between the DQI-DFG components and energy was assessed by Pearson's linear correlation coefficient to determine whether energy intake affected the index score. Since it is unlikely that a diet meets the reference number of servings for all food groups, the Pearson's linear correlation coefficient was used for determining which components had the greatest influence on the total score and possible correlations between them. The DQI-DFG reliability was determined by Cronbach's coefficient alpha.

\section{RESULTS AND DISCUSSION}

\section{Construct validity, internal consistency and reliability}

Table 2 shows the DQI-DFG construct validity and internal consistency. Energy correlated weakly (-0.16 to 0.09) with all food groups, indicating that the final score is not particularly affected by any group. The correlations between the food groups and the total score varied from very weak (0.14) for legumes to moderate (0.52) for sugars and sweets. Inter-component correlations were weak or very weak (-0.16 to 0.39$)$ because the groups were very unique. 
Table 2. Correlations between the score of each component, energy intake, and Diet Quality Index - Digital Food Guide (DQI-DFG) score. Brazil, 2013

\begin{tabular}{|c|c|c|c|c|c|c|c|c|c|c|c|c|c|}
\hline Groups & SS & PSE & $\mathrm{BP}$ & WG & RG & FR & AF & NSV & LE & $\mathrm{MD}$ & Vo & NU & En \\
\hline SS & 1 & & & & & & & & & & & & \\
\hline PSE & $0.14^{\mathrm{b}}$ & 1 & & & & & & & & & & & \\
\hline $\mathrm{BP}$ & 0.07 & $0.39^{b}$ & 1 & & & & & & & & & & \\
\hline WG & $0.16^{\mathbf{b}}$ & -0.05 & $0.13^{b}$ & 1 & & & & & & & & & \\
\hline RG & $0.11^{\mathrm{a}}$ & -0.00 & 0.06 & $0.33^{b}$ & 1 & & & & & & & & \\
\hline$F R$ & $0.10^{\mathrm{a}}$ & 0.07 & $0.11^{\mathrm{a}}$ & $0.11^{\mathrm{a}}$ & $0.18^{b}$ & 1 & & & & & & & \\
\hline $\mathrm{AF}$ & 0.01 & 0.07 & 0.03 & 0.07 & 0.07 & 0.09 & 1 & & & & & & \\
\hline NSV & 0.05 & 0.07 & -0.01 & 0.06 & $0.21^{b}$ & 0.06 & -0.03 & 1 & & & & & \\
\hline $\mathrm{LE}^{\mathrm{c}}$ & 0.08 & -0.10 & -0.01 & 0.01 & 0.05 & -0.01 & 0.06 & -0.03 & 1 & & & & \\
\hline$M D$ & 0.08 & -0.00 & 0.00 & $0.09^{a}$ & 0.04 & -0.06 & -0.02 & -0.10 & -0.10 & 1 & & & \\
\hline Vo & -0.05 & 0.07 & -0.07 & 0.02 & 0.02 & -0.09 & 0.07 & $0.23^{b}$ & 0.05 & -0.01 & 1 & & \\
\hline $\mathrm{NU}$ & $0.10^{\mathrm{a}}$ & 0.07 & $0.23^{b}$ & 0.02 & 0.07 & 0.03 & -0.02 & -0.01 & 0.01 & 0.04 & -0.05 & 1 & \\
\hline En & -0.12 & 0.05 & -0.01 & -0.11 & -0.16 & -0.03 & -0.07 & -0.15 & 0.06 & -0.06 & $0.09^{a}$ & -0.06 & 1 \\
\hline FS & $0.52^{b}$ & $0.45^{b}$ & $0.42^{b}$ & $0.42^{b}$ & $0.39^{b}$ & $0.40^{\mathrm{b}}$ & $0.38^{\mathrm{b}}$ & $0.34^{\mathrm{b}}$ & $0.14^{b}$ & $0.21^{b}$ & $0.27^{b}$ & $0.23^{b}$ & -015 \\
\hline
\end{tabular}

${ }^{a} p<0.05 ;{ }^{b} p<0.01$.

SS: Sugars and Sweets; PSE: Poultry, Seafood, and Eggs; BP: Beef and Pork; WG: Whole Grains and Breads, Tubers, and Roots; RG: Refined Grains and Breads; FR: Fruits; AF: Animal Fat; NSV: Non-Starchy Vegetables; LE: Legumes; MD: Milk and Dairy Products; VO: Vegetable Oils; NU: Nuts; En: Energy; FS: Final Score.

Other studies found similar correlations ${ }^{6,18}$. A cohort study of 13,016 individuals using an index containing six groups (saturated fats, polyunsaturated fats, dietary fibers, sucrose, fruits and vegetables, and fish) found inter-component correlations of -0.52 to 0.28 , except for fruits and vegetables (0.63) with respect to total dietary fibers ${ }^{18}$.

With a Cronbach's alpha of 0.36 , the DQIDFG reliability is considered moderate. Its reliability can be improved by better distinguishing the moderation and adequacy components and revising the number of servings established to each. The original HEI and HEI-05 have Cronbach's alphas of 0.28 and 0.43 , respectively ${ }^{6}$, so the DQI-DFG has comparable reliability. Reliability is a common concern of diet quality index validity studies in view of the multiple dimensions associated with the incorporation of food choices. Diet quality assessment is challenging because ingredients and foods vary greatly across cultures and locations. Waijers' et al. ${ }^{19}$ review emphasized how much the total score of an index is affected by judging the quality of its components arbitrarily, as done by the present study.
Important differences between components can be masked, as other indices have done. Masking is one of the aspects that impair the interpretation of diet quality scores. However, food classification can sometimes be instructive and useful for differentiating diets and producing epidemiological studies.

One DQI-DFG limitation is the exclusion of the component "variety" present in some indices. This methodological option addresses a shortcoming related to the final scores of indices that included variety and different food groups: the result is often high, reducing index sensitivity. The component variety has also been excluded from other indices for the same reason ${ }^{19}$.

The present Diet Quality Index - Digital Food Guide (DQI-DFG) aims to help people meet their nutrient and bioactive compound requirements established by international consensus (Dietary Reference Intakes - DR/20-25). The psychometric analyses used for checking construct validity, internal consistency, and reliability followed the theory behind the Healthy Eating Index- $05^{6}$. Nevertheless, this article mentioned ways in which further studies can improve the accuracy of the study index. 
698 | S CAIVANO \& SMA DOMENE

Present evidence demonstrates that the construct validity, internal consistency, and reliability of the DQI-DFG are similar to those of other indices. McNaughton et al. associated the final score of a diet quality index with the nutrient intakes of the study participants ${ }^{26}$; Funtikova et al. associated it with cardiovascular risk-related biochemical test results and anthropometric measurements ${ }^{27}$; similarly to Funtikova et al., Newby et al. used biochemical test results and a food frequency questionnaire to validate the index, but they did not associate the index score with chronic diseases ${ }^{28}$.

\section{CONCLUSION}

Dietary studies contribute significantly to the knowledge about factors that can modulate health outcomes.

Diet quality is a complex, multidimensional construct, difficult to grasp when its purpose is to determine how diet affects health. Moreover, learning which factors account for good food choices is also of interest. The construct validity, internal consistency, and reliability of the DQI-DFG are comparable to those of other indices. Moreover, the DQI-DFG is an additional resource for dietary studies and may support nutritional care.

\section{REFERENCES}

1. Brasil. Ministério da Saúde. Pesquisa de orçamentos familiares 2008-2009: avaliação nutricional, da disponibilidade domiciliar de alimentos do Brasil. Rio de Janeiro: Ministério da Saúde; 2010.

2. Steemburgo T, DallÁlba V, Gross JL, Azevedo MJ. Fatores dietéticos e síndrome metabólica. Arq Bras Endocrinol Metab. 2007; 51(9):1425-33. doi:10.15 90/S0004-27302007000900004.

3. Barbosa RMS, Colares LG T, Soares EA. Desenvolvimento de guias alimentares em diversos países. Rev Nutr. 2008; 21(4):455-67. doi: 10.1590/S1415-52 732008000400010 .

4. Painter J, Rah JH, Lee YK. Comparison of international food guide pictorial representations. J Am Diet
Assoc. 2002; 102(4):483-9. doi: 10.1016/S0002-82 23(02)90113-6.

5. Jaime PC, Bandoni, DH, Duran ACFL, Fisberg RM. Diet quality index adjusted for energy requirements in adults. Cad Saúde Pública. 2010; 26(11):2121-8. doi: 10.1590/S0102-311X2010001100013.

6. Dixon LB. Updating the Health Eating Index to reflect current dietary guidance. J Am Diet Assoc. 2008; 108(11):1837-42. doi: 10.1016/j.jada.200 8.08.020

7. Ocké MC. Evaluation of methodologies for assessing the overall diet: Dietary quality scores and dietary pattern analysis. Proc Nutr Soc. 2013; 72(2): 191-9. doi: 10.1017/S0029665113000013.

8. Guenther PM, Reedy J, Smith SMK, Reeve BB, Basiotis PP. Development and evaluation of the healthy eating index-2005: Technical report. Alexandria (VA): Center for Nutrition Policy and Promotion; 2007.

9. Guenther PM, Casavale OC, Reedy J, Kirkpatrick $\mathrm{SI}$, Hiza HAB, Kuczynski KJ, et al. Update of the Healthy Eating Index: HEl-2010. J Acad Nutr Diet. 2013; 113(4):569-80. doi: 10.1016/j.jand.2012.1 2.016.

10. United State Department of Agriculture Dietary guidelines of americans, 2010. $7^{\text {th }} \mathrm{ed}$. Washington (DC): USDA, 2010 [cited 2013 Apr 6]. Available from: <http://www.cnpp.usda.gov/dietaryguidelines. htm>.

11. Fisberg RM, Slater B, Barros RR, Lima FD, César CLG, Carandina L, et al. Índice de qualidade da dieta: avaliação da adaptação e aplicabilidade. Rev Nutr. 2004; 17(1):301-8. doi: 10.1590/S1415-5273200 4000300003.

12. Previdelli AN, Andrade SC, Pires MM, Ferreira SRG, Fisberg RM, MArchioni DM. A revised version of the healthy eating index for the Brazilian population. Rev Saúde Pública. 2011; 45(4):794-8. doi: 10.1590/S0034-89102011005000035.

13. Brasil. Ministério da Saúde. Guia alimentar para a população brasileira: promovendo alimentação saudável. Brasília: Ministério da Saúde; 2006.

14. Caivano S, Ferreira BJ, Domene SMA. Avaliação da usabilidade do guia alimentar digital móvel segundo a percepção dos usuários. Ciênc Saúde Colet. 2013 [acesso 2013 set 9]. Disponível em: <http:// www.cienciaesaudecoletiva.com.br/artigos/artigo_ int.php?id_artigo=13792>.

15. Willett WC, Skerrett J. Eat, drink, and be healthy: The Harvard Medical School guide to healthy eating. Washington (DC): Harvard School of Medicine; 2005.

16. Harvard Medical School. Healthy eating plate dishes out sound diet advice: More specific than MyPlate, 
it pinpoints the healthiest food choices. Harv Heart Lett. 2011 [cited 2012 Aug 18]; 22(4):6. Available from: <http://harvardpartnersinternational. staywellsolutions online.com/HealthNewsLetters/ 69, H1211e>.

17. Harvard School of Public Health. Food pyramids and plates: What should you really eat? Boston (MA): Harvard School of Public Health; [2011] [cited 2012 Ago 18]. Available from: <http://www.hsph. harvard.edu/nutritionsource/what-should-you-eat/ pyramid-full-story/index.html>.

18. Drake I, Gullberg Bo, Ericson U, Sonestedt E, Nilsson J, Wallström P, et al. Development of a diet quality index assessing adherence to the Swedish nutrition recommendations and dietary guidelines in the Malmö diet and cancer cohort. Public Health Nutri. 2011; 14(5):835-45. doi: 10.1017/S13689800100 03848.

19. Waijers PMCM, Feskens EJM, Ocké MC. A critical review of predefined diet quality scores. Br J Nutr. 2007; 97(2):219-31. doi: 10.1017/S000711450 7250421.

20. Institute of Medicine. Dietary reference intakes: Calcium, phosphorus, magnesium, vitamin D and fluoride. Washington (DC): National Academy Press; 2010.

21. Institute of Medicine. Dietary reference intakes: Thiamin, riboflavin, niacin, vitamin B6, folate, vitamin $B_{12}$, pantothenic acid, biotin and choline. Washington (DC): National Academy Press; 1998.

22. Institute of Medicine. Dietary reference intakes: Vitamin C, vitamin E, selenium and carotenoids. Washington (DC): National Academy Press; 2000.
23. Institute of Medicine. Dietary reference intakes: Vitamin A, vitamin K, arsenic, boron, chromium, copper, iodine, iron, manganese, molybdenum, nickel, silicon, vanadium and zinc. Washington (DC): National Academy Press; 2001.

24. Institute of Medicine. Dietary reference intakes: Energy, carbohydrate, fiber, fat, fatty acids, cholesterol, protein and amino acids. Washington (DC): National Academy Press; 2005.

25. Institute of Medicine. Dietary reference intakes: Water, potassium, sodium, chloride and sulfate. Washington (DC): National Academy Press; 2005.

26. McNaughton SA, Ball K, Crawford D, Mishra GD. An index of diet and eating patterns is a valid measure of diet quality in an Australian population. J Nutr. 2008; 138(1):86-93.

27. Funtikova A, Baena-Díez JM, Koebnick C, Gomes SF, Covas MI, Goday A, et al. Validity of a short diet-quality index to predict changes in anthropometric and cardiovascular risk factors: A simulation study. Eur J Clin Nutr. 2012; 66(12):1369-71. doi: 10.10 38/ejcn.2012.131.

28. Newby PK, Hu FB, Rimm EB, Smith-Wamer SA, Feskanich D, Sampson L, et al. Reproducibility and validity of the diet quality index Revised as assessed by use of a food-frequency questionnaire. Am J Clin Nutr. 2003; 78(5):941-9.
Received on: 11/1/2013 Final version on: 11/10/2013 Approved on: 29/10/2013 
